\title{
Potensi Pelaksanaan Self Monitoring Blood Glucose Pada Pasien Diabetes Dalam Meningkatkan Kualitas Hidup dan Kontrol Glikemik
}

\author{
Pandan Enggarwati ${ }^{1}$, Debie Dahlia ${ }^{2}$, Sri Yona ${ }^{3}$ \\ ${ }^{1}$ Magister Keperawatan Medikal Bedah, Fakultas Ilmu Keperawatan, Universitas Indonesia \\ ${ }^{2}$ Departemen Keperawatan Medikal Bedah, Fakultas Ilmu Keperawatan Universitas Indonesia \\ Email : pandanenggarwati@gmail.com ${ }^{1}$, debie_dahlia@yahoo.com ${ }^{2}$, sriyona@ui.ac.id ${ }^{3}$
}

\begin{abstract}
Abstrak
Pendahuluan: Dominasi penyakit di Indonesia saat ini mulai bergeser ke arah penyakit kronis, salah satunya diabetes. Sejak ditegakannya diagnosis diabetes, maka manajemen diabetes harus dilakukan secara kontinyu sehingga berdampak pada perubahan kualitas hidup pasien. Kualitas hidup terkait kesehatan merupakan indikator kesehatan yang mencakup konsep subyektif dan multidimensi yang saling terkait, termasuk didalamnya menilai aspek fisik, fungsional, psikologis, dan agama. Self monitoring blood glucose (SMBG) merupakan bagian dari manajemen diabetes yang memungkinkan menjadi kontrol indeks glikemik dan kualitas hidup. Namun potensi pelaksanaan SMBG perlu diketahui lebih lanjut.

Tujuan: Tujuan penulisan untuk mengetahui potensi SMBG dalam manajemen diabetes dan kaitannya dengan indeks glikemik serta kualitas hidup.

Metode: Telaah literatur dari artikel ini didapatkan dari EBSCOhost, PubMed, ProQuest, Willey Library Online dan ScienceDirect sejak tahun 2014 - 2019.

Hasil: Hasil ditemukan bahwa SMBG memberikan dampak yang signifikan pada HRQoL dan kontrol indeks glikemik.

Kesimpulan: Peranan perawat dalam pemberian edukasi yang komprehensif diperlukan untuk meningkatkan pengetahuan penggunaan SMBG
\end{abstract}

Kata Kunci: pemantauan gula darah mandiri, kualitas hidup, diabetes, kontrol glikemik

\section{Pendahuluan}

Diabetes merupakan penyakit kronis yang menjadi penyebab utama morbiditas, kecacatan dan kematian. ${ }^{19}$ Berdasarkan data dari WHO (2016) dalam Global Report on Diabetes,

\begin{abstract}
Introduction: Diseases that are considered particularly dominant in Indonesia are now starting to shift toward chronic diseases and one of which is diabetes mellitus (DM). Ever since a patient is diagnosed with DM, DM management must be carried out continuously and it will bring changes to the patients' lifestyle. Health-Related Quality of Life (HRQoL) is a health indicator which covers interrelated subjective and multidimensional concepts, including assessment of physical, functional, psychological, and religious aspects. Self Monitoring Blood Glucose (SMBG) is a part of DM disease management which allows control of the glycemic index and quality of life. However, potential benefits of SMBG implementation needs to be discovered further.

Objective: The purpose of this article is to determine the potential of SMBG in DM management and its relation to the glycemic index and quality of life.

Methods: Literature review of this article based on EBSCOhost, PubMed, ProQuest, Willey Library Online dan ScienceDirect from 2013 - 2019. Results: The result shows that SMBG had a significant impact on HRQoL and glycemic index control.
\end{abstract}

Conclusion: The role of nurses in the provision of

Keywords: self monitoring blood glucose, quality of life, diabetes, glycemic control

prevalensi kejadian diabetes pada tahun 2013 sebanyak 382 juta jiwa. ${ }^{1}$ Pada tahun 2014 jumlah pasien diabetes mengalami peningkatan menjadi 422 juta jiwa atau s ekitar 8,5\% dari 
semua populasi penduduk dunia. Insiden dan prevalensi penyakit ini diperkirakan akan terus meningkat terutama di negara berkembang, salah satunya yaitu Indonesia. Di Indonesia, jumlah kasus diabetes pada tahun 2015 sebanyak 10 juta jiwa dan menempati urutan ke-5 di dunia. ${ }^{2}$ ditaksir pada tahun 2035 penderita diabetes meningkat menjadi 592 juta jiwa. ${ }^{3}$ Kompleksitas penyakit diabetes mengharuskan penderitanya menjalankan perawatan medis secara berkelanjutan dengan tujuan menurunkan risiko komplikasi melalui pengontrolan glikemik. Sejak ditegakannya diagnosis pada penderita diabetes, maka manajemen diabetes harus dilakukan secara kontinyu yang secara langsung berdampak pada perubahan gaya hidup serta biaya perawatan. ${ }^{4}$ Manajemen diabetes meliputi pemberian medikasi insulin/per oral, self monitoring blood glucose (SMBG), diet seimbang, dan aktivitas fisik teratur. Selain itu, tidak bisa dipungkiri pasien DM akan berisiko hidup di dalam ketakutan akan komplikasi di masa depan, mengalami hipoglikemia, dan kematian dini.

Kualitas hidup terkait kesehatan atau (HRQoL) merupakan indikator kesehatan yang penting. Konsep HRQoL mencakup konsep subyektif dan multidimensi yang saling terkait, termasuk di dalamnya menilai aspek fisik, fungsional, psikologis, dan agama. Evaluasi HRQoL pada pasien dengan penyakit kronis dan hubungannya terkait dengan manajemen terapi telah banyak diteliti dan diakui memiliki efek yang signifikan. ${ }^{5}$ Oleh karena itu, mengingat pentingnya $\mathrm{HRQoL}$ pada pasien dengan penyakit kronis seperti DM, saat ini HRQoL tidak hanya dianggap sebagai prediktor yang signifikan terhadap hasil kesehatan, namun telah dianggap sebagai hasil kesehatan yang signifikan. ${ }^{6,7}$

Berangkat dari kompleksitas penyakit diabetes, ada pemikiran berikutnya mengenai bagaimana aspek manajemen diabetes akan mempengaruhi kontrol glikemik dan HRQoL. Di satu sisi, episode berulang hipoglikemia dan ketakutan episode ini telah terbukti merusak HRQoL. ${ }^{8}$ Di sisi lain, hiperglikemia dan ketakutan atau komplikasi mikrovaskular juga berkaitan dengan HRQoL yang lebih buruk., ${ }^{9} 10$ Oleh karena itu, artikel ini bertujuan untuk untuk menggali potensi penerapan self monitoring blood glucose terhadap kontrol glikemik dan HRQoL pada pasien dengan DM Tipe 2 dimana jurnal yang sudah ada saat ini masih terbatas membahas peran selfmonitoring blood glucose terhadap indeks glikemik.

\section{Metode}

Desain yang digunakan dalam penelisan ini adalah tinjauan literatur. Artikel dipilih berdasarkan kriteria pencarian: dalam a) berbahasa inggris, b) publikasi antara tahun $2013-2019$, c) ketersedian teks lengkap, dan d) penelitian kualitatif maupun kuantitatif. Setelah melakukan pencarian yang sesuai kriteria inklusi. Artikel yang memenuhi syarat akan dimasukan dalam analisa jika mengandung: konsep teori a) SMBG sebagai salah satu manajemen diri pasien DM dalam mengontrol indeks glikemik dan persepsi Health Related Quality of Life (HRQoL), b) peran perawat dalam pelaksanaan pemantauan SMBG, dan c) kendala pelaksanaan SMBG.

Sumber berasal dari jurnal dan artikel dikumpulkan dari database berbasis ilmiah (EBSCOhost, PubMed, ProQuest, Willey Library Online dan ScienceDirect). Pencarian sumber dilakukan pada bulan September sampai dengan Oktober 2019 dengan kata kunci $d i$ abetes management - self monitoring blood glucose - quality of life - role of nursing. Penggabungan kata kunci saat pencarian di data base menggunakan operator Boolean "AND" and "OR" (Lolos Uji Etik FIK UI Nomor: SK132/UN2.F12.D1.2.1/ETIK/2020).

\section{Hasil}

\section{Seleksi Studi}

Hasil pencarian didapatkan 1512 artikel, selanjutnya dilakukan penyaringan awal judul untuk mengeluarkan artikel yang tidak sesuai dengan tujuan studi yang sedang dilakukan oleh peneliti.

\section{Analisis Data}


Dari beberapa jurnal yang sudah diseleksi dan dikumpulkan, terdapat 12 jurnal yang membahas sesuai dengan tujuan peneliti. Selanjutnya, jurnal yang dikumpulkan dilakukan analisis hasilnya, kemungkinan perkembangannya, dan implikasinya di bidang keperawatan. Beberapa topik artikel yang akan dianalisa meliputi manajemen diri pasien diabetes (self monitoring blood glucose) terhadap kontrol glikemik dan kualitas hidup sebanyak lima buah artikel, peran perawat dalam pelaksanaan SMBG sebanyak tiga artikel, dan kendala pelaksanaan SMBG sebanyak empat artikel. Hasil tinjauan literatur terangkum dalam tabel tinjauan literatur di bawah ini. 


\section{Tabel Tinjauan Literatur}

\begin{tabular}{|c|c|c|c|c|c|c|c|}
\hline No & Judul & Tahun & Penulis & Masalah & Tujuan & Metode \& Sampel & Hasil \\
\hline 1 & $\begin{array}{l}\text { Correlation } \\
\text { between pa- } \\
\text { rameters of } \\
\text { self-monitor- } \\
\text { ing of blood } \\
\text { glucose and } \\
\text { the percep- } \\
\text { tion of } \\
\text { health- re- } \\
\text { lated quality } \\
\text { of life in pa- } \\
\text { tients with } \\
\text { type } 1 \text { diabe- } \\
\text { tes mellitus }\end{array}$ & 2017 & $\begin{array}{l}\text { Paula, J. } \\
\text { S., Braga, } \\
\text { L. D., } \\
\text { Moreira, } \\
\text { R. O., \& } \\
\text { Kupfer, R. }\end{array}$ & $\begin{array}{l}\text { Diabetes merupakan penyakit kronis } \\
\text { yang menjadi penyebab utama mor- } \\
\text { biditas, kecacatan dan kematian. Self } \\
\text { Monitoring Blood Glucose (SMBG) } \\
\text { telah diterima sebagai bagian integral } \\
\text { dalam manajemen DM terutama untuk } \\
\text { penderita yang menggunakan insulin. } \\
\text { Kualitas hidup terkait kesehatan } \\
\text { (HRQoL) merupakan indikator } \\
\text { kesehatan yang penting. Bagaimana } \\
\text { aspek terkait pengelolaan penderita } \\
\text { DM tipe I (SMBG) akan } \\
\text { mempengaruhi persepsi HRQoL. }\end{array}$ & $\begin{array}{l}\text { Mengevaluasi ko- } \\
\text { relasi (SMBG) } \\
\text { terhadap persepsi } \\
\text { kualitas hidup } \\
\text { terkait kesehatan } \\
\text { (HRQoL) pada } \\
\text { pasien DM tipe } 1\end{array}$ & $\begin{array}{l}\text { Desain: Cross sectional } \\
\begin{array}{l}\text { Purposive samping berjumlah } 50 \\
\text { orang }\end{array} \\
\text { Kriteria inklusi: } \\
\text { Didiagnosis T1DM > } 1 \text { tahun; usia } \\
\begin{array}{l}\text { 18-50 tahun; menjalani multiple in- } \\
\text { sulin injection rutin }\end{array} \\
\text { Kriteria eksklusi: } \\
\text { Pasien T1DM dengan komplikasi } \\
\text { CKD tahap akhir, depresi, dan ke- } \\
\text { hamilan }\end{array}$ & $\begin{array}{l}\text { PAID berkorelasi positif terhadap } \\
\text { MGL }(\mathrm{r}=0,52 ; \mathrm{p}<0,001) \text { dan } \\
\text { HbA1c }(\mathrm{r}=0,36 ; \mathrm{p}<0,0097) \text {, dan } \\
\text { berbanding terbalik dengan } \mathrm{GV}(\mathrm{r} \\
=0,17 ; \mathrm{p}=0,23) \text { atau jumlah epi- } \\
\text { sode hipoglikemik }(\mathrm{r}=0,15 ; \mathrm{p}= \\
0,17 \text { untuk glukosa }<70 \mathrm{mg} / \mathrm{dL} \\
\text { dan } \mathrm{r}=0,02 ; \mathrm{p}=0,85 \text { untuk glu- } \\
\text { kosa }<50 \mathrm{mg} / \mathrm{dL}) \text {. Hasil regresi } \\
\text { linier berganda, hanya MGL yang } \\
\text { tetap independen terhadap skor } \\
\text { PAID. Skor DQoL memiliki ko- } \\
\text { relasi positif dengan MG) ( } \mathrm{r}= \\
0,45 ; \mathrm{p}=0,001), \text { tetapi tidak } \\
\text { dengan HbA1c }(\mathrm{r}=0,23 ; \mathrm{p}=0,09), \\
\text { GV }(\mathrm{r}=0,20 ; \mathrm{p}=0,16), \text { atau } \\
\text { jumlah episode hipoglikemik }(\mathrm{r}= \\
0,06 \mathrm{p}=0,68) .\end{array}$ \\
\hline 2 & $\begin{array}{l}\text { The Impact } \\
\text { of Structured } \\
\text { SMBG Com- } \\
\text { bined With } \\
\text { Intensive } \\
\text { Education } \\
\text { on HbAlc } \\
\text { Levels, } \\
\text { Hospitaliza- } \\
\text { tions, and } \\
\text { Quality-of- } \\
\text { Life } \\
\text { Parameters } \\
\text { in Insulin- }\end{array}$ & 2017 & $\begin{array}{l}\text { Lalić, N. } \\
\text { M., Lalić, } \\
\text { K., Jotić, } \\
\text { A., } \\
\text { Stanojević, } \\
\text { D., } \\
\text { Živojinovi } \\
\text { ć, D., } \\
\text { Janićijević, } \\
\text { A., \& } \\
\text { Parkin, C }\end{array}$ & $\begin{array}{l}\text { Mempertahankan kontrol glikemik } \\
\text { yang optimal terbukti meningkatkan } \\
\text { hasil klinis pada diabetes tipe } 1 \text { dan } 2 . \\
\text { Namun, hal tersebut menjadi tan- } \\
\text { tangan bagi penderita dan penyedia } \\
\text { layanan kesehatan. Penderita diabetes } \\
\text { menghabiskan sekitar } 8750 \text { jam per ta- } \\
\text { hun untuk mengelola penyakit diabe- } \\
\text { tes sehingga risiko penurunan akan } \\
\text { kelelahan sering terjadi. Beberapa } \\
\text { penelitian menunjukkan bahwa } \\
\text { penggunaan SMBG terstruktur kom- } \\
\text { binasi dengan pendidikan dan } \\
\text { dukungan tenaga kesehatan mampu } \\
\text { mendorong perubahan perilaku yang }\end{array}$ & $\begin{array}{l}\text { Menilai efek } \\
\text { pemantauan man- } \\
\text { diri glukosa darah } \\
\text { (SMBG) ter- } \\
\text { struktur, dalam } \\
\text { kombinasi dengan } \\
\text { pendidikan inten- } \\
\text { sif. }\end{array}$ & $\begin{array}{l}\text { Desain: RCT } \\
\begin{array}{l}\text { Purposive samping berjumlah } 400 \\
\text { orang }\end{array} \\
\text { Kriteria inklusi : } \\
\text { Usia } 18-70 \text { tahun; HbA1c } \geq 8 \% \text {; di- } \\
\text { obati dengan insulin (monoterapi } \\
\text { atau dalam kombinasi dengan agen } \\
\text { antidiabetes oral); dan bersedia / } \\
\text { mampu melakukan pengukuran } \\
\text { SMBG. } \\
\text { Kriteria eksklusi: }\end{array}$ & $\begin{array}{l}\text { Mean }( \pm \mathrm{SD}) \text { HbA1c dalam kohort } \\
\text { penuh meningkat secara signifikan } \\
\text { dari awal pada } 6 \text { bulan }(8,85 \pm \\
1,17 \% \text { vs } 7,91 \pm 1,24 \%, \mathrm{P}<0,01) \text {. } \\
\text { Peningkatan signifikan dalam } \\
\text { frekuensi SMBG rata-rata per } \\
\text { minggu terlihat pada } 6 \text { bulan } \\
\text { dibandingkan awal }(14,6 \text { / minggu } \\
\text { vs } 4,3 \text { / minggu, P }<0,001) \text {. Jumlah } \\
\text { rata-rata ( } \pm \text { SE) rawat inap karena } \\
\text { kondisi metabolisme secara signif- } \\
\text { ikan lebih rendah selama studi } 6 \\
\text { bulan dibandingkan dengan peri- } \\
\text { ode } 6 \text { bulan sebelum penelitian } \\
(0,14 \pm 0,04 \text { vs } 0,59 \pm 0,09) \text {. Skor }\end{array}$ \\
\hline
\end{tabular}




\begin{tabular}{|c|c|c|c|c|c|c|c|}
\hline & $\begin{array}{l}\text { Treated Pa- } \\
\text { tients } \\
\text { With Diabe- } \\
\text { tes at Pri- } \\
\text { mary Care } \\
\text { in Serbia: } \\
\text { The Multi- } \\
\text { center SPA- } \\
\text { EDU Study }\end{array}$ & & & $\begin{array}{l}\text { diinginkan, meningkatkan motivasi } \\
\text { dan pemberdayaan pasien, meningkat- } \\
\text { kan pemahaman pasien tentang re- } \\
\text { jimen pengobatan dan memfasilitasi } \\
\text { intensifikasi terapi, yang mengarah } \\
\text { pada peningkatan hasil klinis dan } \\
\text { kualitas hidup. }\end{array}$ & & $\begin{array}{l}\text { Memiliki penyakit bawaan, ibu } \\
\text { hamil dan menyusui. }\end{array}$ & $\begin{array}{l}\text { DDS menurun dari } 39,6 \pm 13,9 \\
\text { menjadi } 33,9 \pm 14,5, \mathrm{P}<0,01\end{array}$ \\
\hline 3 & $\begin{array}{l}\text { Health-re- } \\
\text { lated quality } \\
\text { of life in } \\
\text { people with } \\
\text { type } 1 \text { Dia- } \\
\text { betes Melli- } \\
\text { tus: Data } \\
\text { from the } \\
\text { Brazilian } \\
\text { Type 1 Dia- } \\
\text { betes Study } \\
\text { Group }\end{array}$ & 2015 & $\begin{array}{l}\text { Braga de } \\
\text { Souza, A. } \\
\text { C. C., } \\
\text { Felício, J. } \\
\text { S., Koury, } \\
\text { C. C., } \\
\text { Neto, J. F. } \\
\text { A., Miléo, } \\
\text { K. B., San- } \\
\text { tos, F. M., } \\
\text { ‥ Jezini, } \\
\text { D. L }\end{array}$ & $\begin{array}{l}\text { Individu dengan diabetes mengalami } \\
\text { penurunan kualitas hidup terkait } \\
\text { kesehatan (HRQoL) dibandingkan } \\
\text { dengan individu tanpa diabetes di- } \\
\text { mana HRQoL yang buruk pada pasien } \\
\text { dengan diabetes dikaitkan dengan } \\
\text { hasil yang merugikan, termasuk pen- } \\
\text { ingkatan mortalitas. Beberapa factor } \\
\text { yang memicu dampak negatif diabetes } \\
\text { pada kualitas hidup (QoL), meliputi } \\
\text { ketakutan akan hipoglikemia atau } \\
\text { komplikasi sekunder, kekhawatiran di } \\
\text { masa depan akan stigmatisasi, ke- } \\
\text { hilangan fleksibilitas, citra diri yang } \\
\text { buruk, proteksi berlebihan, usia, kelas } \\
\text { ekonomi, pendidikan, etnis, penge- } \\
\text { tahuan tentang penyakit dan tuntutan } \\
\text { harian terapi diabetes (yaitu terapi in- } \\
\text { sulin, pemantauan glukosa darah). } \\
\text { Penelitian mengenai dampak dari } \\
\text { kontrol glikemik pada kualitas hidup } \\
\text { pasien diabetes masih terbatas. }\end{array}$ & $\begin{array}{l}\text { Mengevaluasi } \\
\text { kualitas hidup } \\
\text { terkait kesehatan } \\
\text { (HRQoL) pasien } \\
\text { DM tipe } 1 \text { di Bra- } \\
\text { sil }\end{array}$ & $\begin{array}{l}\text { Desain: Retrospective, cross sec- } \\
\text { tional } \\
\begin{array}{l}\text { Purposive samping berjumlah } 3,005 \\
\text { orang }\end{array} \\
\text { Kriteria inklusi: } \\
\text { Pasien yang didiagnosis dengan } \\
\text { DM tipe 1 oleh dokter (berdasarkan } \\
\text { presentasi klinis klinis serta kebu- } \\
\text { tuhan menggunakan insulin terus } \\
\text { menerus sejak diagnosis), dengan } \\
\text { waktu tindak lanjut di masing-mas- } \\
\text { ing pusat lebih dari atau sama } \\
\text { dengan } 6 \text { bulan., dan lebih dari } 10 \\
\text { tahun. } \\
\text { Kriteria eksklusi: Pasien hamil dan } \\
\text { menyusui, memiliki riwayat infeksi } \\
\text { akut atau KAD dalam } 3 \text { bulan tera- } \\
\text { khir. }\end{array}$ & $\begin{array}{l}\text { Penilaian HRQoL melalui } \\
\text { kuesioner EuroQol menunjukkan } \\
\text { bahwa skor rata-rata kualitas } \\
\text { hidup pasien DM di Brasil jauh } \\
\text { lebih rendah daripada yang } \\
\text { ditemukan dalam dua studi ber- } \\
\text { basis populasi DM Tipe } 1 \text { lainnya } \\
\text { yang dilakukan di Eropa (EQ- } \\
\text { VAS dari Belanda, Inggris) dan } \\
\text { Brazil masing-masing } 80,8 \pm 15,2 \text {, } \\
75,1 \pm 18,4 \text { dan } 72,5 \pm 22 . \text { Selain } \\
\text { itu, data menunjukkan bahwa } \\
\text { kontrol glikemik yang lebih baik } \\
\text { dapat berdampak positif pada } \\
\text { HRQoL pasien dengan DM Tipe } \\
1 \text {, menyiratkan bahwa setiap pen- } \\
\text { gurangan } 1 \% \text { dalam hemoglobin } \\
\text { terglikasi dapat menyebabkan pen- } \\
\text { ingkatan } 1,5 \text { poin dalam status } \\
\text { kesehatan umum yang dinilai oleh } \\
\text { EuroQol. }\end{array}$ \\
\hline 4 & $\begin{array}{l}\text { Effect of a } \\
\text { Nurse-Led } \\
\text { Diabetes } \\
\text { Self-Man- }\end{array}$ & 2018 & $\begin{array}{l}\text { Azami, G., } \\
\text { Soh, K. L., } \\
\text { Sazlina, S. } \\
\text { G., } \\
\text { Salmiah, } \\
\end{array}$ & $\begin{array}{l}\text { Prevalensi diabetes di Iran diproyeksi- } \\
\text { kan menjadi } 9,2 \text { juta pada tahun } 2040 . \\
\text { Guna mencegah perkembangan kom- } \\
\text { plikasi diabetes diperlukan upaya in- } \\
\text { tensif untuk mencapai kontrol }\end{array}$ & $\begin{array}{l}\text { Menyelidiki efek- } \\
\text { tivitas pendidikan } \\
\text { self management } \\
\text { diabetes yang } \\
\text { dipimpin perawat }\end{array}$ & $\begin{array}{l}\text { Desain: RCT } \\
\text { Purposive samping berjumlah } 142 \\
\text { orang }\end{array}$ & $\begin{array}{l}\text { Pasien dalam kelompok intervensi } \\
\text { menunjukkan peningkatan signif- } \\
\text { ikan dalam HbA1c, tekanan darah, }\end{array}$ \\
\hline
\end{tabular}


agement Education Program on Glycosylated

Hemoglobin among Adults with

Type 2 Diabetes
M

S.,

Aazami,

S.,

pisinga mamp menginspirasi peru-

Mozafari, bahan positif dan mengubah pem-

M., \& berian layanan kesehatan dengan ber-

Tagh- fungsi sebagai jembatan antara teori

inejad, H. dan praktik. Dalam edukasi mana-

jemen diri diabetes (DSME), praktik perawat diposisikan secara ideal untuk memberikan pemantauan, umpan balik yang disesuaikan, dan pendidikan tentang aspek-aspek kunci dari manajemen diri.

\begin{tabular}{ll}
\hline 5 & Enhanced \\
self-monitor- \\
ing blood \\
glucose in \\
non-insulin- \\
requiring \\
Type 2 dia- \\
betes: A \\
qualitative \\
study in pri- \\
mary care
\end{tabular}

\begin{tabular}{ll}
\hline $6 \quad$ Exploring \\
the motiva- \\
tions behind \\
misreporting \\
self-meas- \\
ured blood \\
glucose
\end{tabular}

$\begin{array}{ll}2018 & \text { Brackney, } \\ & \text { D. E }\end{array}$

Kompleksitas pemantauan glukosa darah mandiri (SMBG) dalam diabetes Tipe 2 membutuhkan pemahaman yang lebih mendalam mengenai pengalaman pasien diabetes dalam menjalani self monitoring blood glucose secara terstruktur. Keterampilan berhitung klien berkontribusi terhadap respons mereka terhadap pembacaan glukosa darah. Penggunaan wa- diberikan oleh wancara motivasi oleh perawat untuk perawat. meningkatkan self-efficacy regulasi

klien menjadi penting untuk perspektif teoritis penelitian.

$\begin{array}{llll}2016 & \text { Blackwell, } & \text { Kemajuan dalam manajemen diri } & \text { Mengetahui moti- } \\ & \text { M., } & \text { pasien diabetes sudah semakin maju. } & \text { vasi di balik } \\ \text { Tomlinson, } & \text { Namun, pelaporan self monitoring } & \text { kesalahan } \\ & \text { P. A., } & \text { blood glucose (SMBG) tetap menjadi } & \text { pelaporan SMBG } \\ & \text { Rayns, J., } & \text { hal mendasar. Sebab, kesalahan } & \text { pada remaja dia- } \\ & \text { Hunter, J., } & \text { pelaporan SMBG pada keluarga dan } & \text { betes tipe 1. } \\ \text { Sjoeholm, } & & \end{array}$

\section{Menggambarkan} pengalaman pasien diabetes tipe 2 (non insulin terapi) dalam intervensi pemantauan glukosa darah mandiri terstruktur yang derikan terhadap nilai he-

moglobin

glikosilasi pemantauan glukosa darah mandiri

\section{Desain: Fenomenologi}

Purposive sampling berjumlah 15 orang.

Kriteria inklusi:

Didiagnosis diabetes tipe 1 minimal $\geq 6$ bulan dan mengkonsumsi $>0,5$

Berusia $\geq 18$ tahun, di diagnosis DM

$\mathrm{HbA} 1 \mathrm{c} \geq 8 \%$.

Kriteria eksklusi:

Memiliki disfungsi kognitif, kedarah $(\geq 180 / 110$ mmHg), gg. pendengaran, gg. penglihatan, anemia hemolitik, dan plikasi diabetes akut atau kronis, komkesulitan besar dalam kegiatan kehidupan sehari-hari.

Purposive sampling berjumlah 11 Kriteria inklusi: terstruktur.

berat badan, harapan efikasi, harapan hasil, dan perilaku manajemen diri diabetes.

Pasien melakukan pemantauan ang dari dua tahun dengan non in- mastikan diagnosis DM tipe 2, mengurangi ketakutan terhadap penyakit, mengetahui dampak perilaku kesehatan terhadap nilai glukosa darah, dan mengapresiasi diri atas upaya manajemen diri diabetes yang telah dijalani

Usia rata-rata peserta adalah 15,7 tahun, $60 \%$ adalah laki-laki, dengan $67 \%$ menggunakan injeksi insulin harian, dan $33 \%$ pada pompa insulin. Median HbA1c 84 $\mathrm{mmol} / \mathrm{mol}$. 


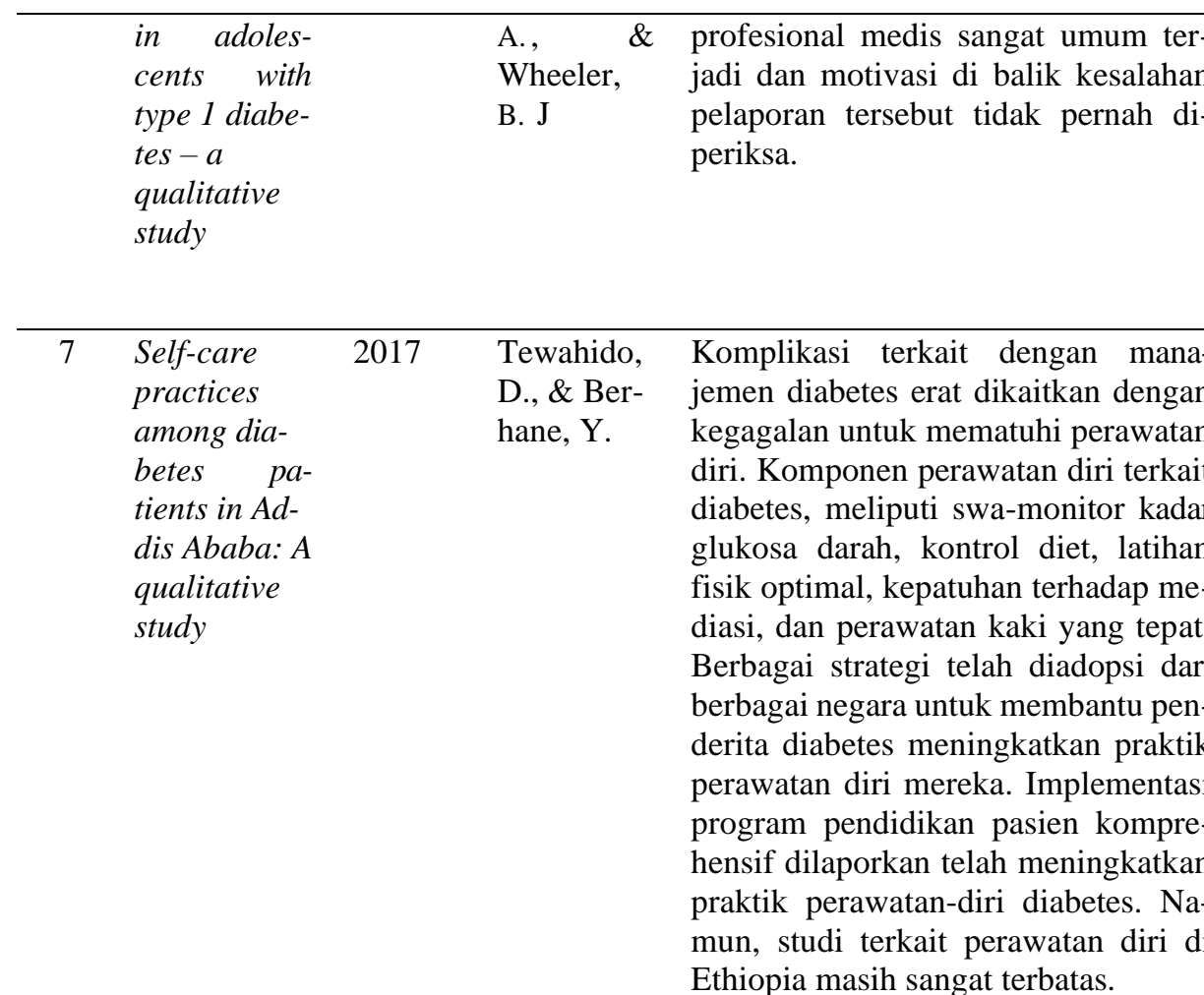

\begin{tabular}{clll}
\hline 8 & $\begin{array}{l}\text { Mental dis- } \\
\text { tress and }\end{array}$ & Tanaka, Self monitoring blood glucose \\
health-re- & N., Yabe, (SMBG) secara luas diakui sebagai \\
lated quality & D., Muro- komponen utama dari pendidikan ma- \\
of life among & tani, K., najemen diri diabetes terintegrasi. Na- \\
type 1 and & Ueno, S., mun, SMBG membebani pasien \\
type 2 diabe- & Kuwata, dengan tekanan mental yang dicurigai \\
tes patients & H., Hama- dapat menurunkan kualitas hidup \\
using self- & moto, Y., terkait kesehatan (QOL) dalam be- \\
monitoring & .. Satoh, J. berapa kasus. Nyeri tusukan jari meru- \\
pakan salah satu beban mental
\end{tabular}

Mengevaluasi

\section{SMBG}

berkaitan dengan

gangguan mental

pada pasien diabe-

tes.

Tujuan dari
penelitian ini ada-
lah untuk meng-
gambarkan prak-
tik perawatan diri
di antara individu
dengan diabetes
tipe II di Addis
Ababa, Ethiopia.

unit insulin / kg / hari; berusia 12 - Tiga tema utama didapatkan

19 tahun; mampu berbahasa Inggris; mengenai motivasi yang bersedia mendiskusikan perilaku mengarah pada kesalahan SMBG yang tidak dilaporkan. pelaporan SMBG, yaitu mencapai manfaat potensial, menghindari konsekuensi negatif, dan Kriteria eksklusi:

Memiliki masalah psikososial akut.

diri

Desain: Fenomenologi

Purposive sampling berjumlah 13 orang yang direkrut dari klinik diabetes rawat jalan dari dua rumah sakit umum di Addis Ababa pada November 2013 dan Februari 2014.

Kriteria inklusi: didiagnosis DM Tipe 2 minimal 5 tahun terakhir dan berusia antara 35-65 tahun.

Praktek perawatan diri secara keseluruhan tidak memadai. Sebagian besar pasien melaporkan pemantauan gula darah secara tidak teratur. Rekomendasi diet dan latihan fisik tidak dipraktekkan secara memadai oleh sebagian besar peserta. Sebagian besar pasien lebih patuh pada resep obat. Pasien umumnya kurang informasi / pengetahuan yang tepat mengenai pentingnya perawatan Kriteria eksklusi : Pasien DM tipe 2 diri dan bagaimana hal itu harus dengan masalah mental dilaksanakan. Berdasarkan perilaku yang dilaporkan, kami mengidentifikasi tiga kategori utama pasien; yang merupakan 'usaha untuk patuh', 'bingung' dan 'lalai'. Dari total 517 pasien DM tipe 1 Desain: Cross sectional menunjukkan bahwa $46.0 \%$ penderita DM tipe 1 dan $37.5 \%$ pasien

DM tipe 2 melaporkan 'nyeri', dan

Kriteria inklusi : (i) pasien DM tipe 1 atau DM tipe 2 berusia $\geq 20$ tahun dan <90 tahun; menggunakan SMBG selama $\geq 3$ bulan; mampu menjawab kuesioner; dan menerima bahwa pasien yang melaporkan 'nyeri' menunjukkan skor Profil Mood States 2 yang jauh lebih tinggi, skor kualitas hidup terkait terapi diabetes yang lebih rendah 
of blood glu-

cose: $\quad A$

cross-sec-

tional ques-

tionnaire

study in $\mathrm{Ja}$ -

pan. penggunaan SMBG yang paling jelas.

Meskipun telah ada perangkat glikom-

eter yang dapat mengurangi rasa saki

saat tertusuk, namun hal tersebut men-

jadi beban utama manajemen diabetes

secara keseluruhan. insulin dan / atau agonis reseptor peptida-1 seperti glukagon.

Kriteria eksklusi : Pasien DM dengan demensia dan / atau gangguan psikologis dan / atau kejiwaan, atau jika pasien dianggap tidak memenuhi syarat penelitian oleh DPJP.

Self monitoring blood glucose Menyelidik

(SMBG) direkomendasikan secara keefektifan

self-monitor-

ing of blood

glucose re-

duces gly-

cated hemo-

globin in in-

sulin-treated

diabetes

$\begin{array}{ll}\text { Noriko } & S \\ \text { Kato, } & \text { (ST } \\ \text { Jinyan Cui, } & \text { luas } \\ \text { Mitsutoshi } & \text { d } \\ \text { Kato } & \text { p } \\ & \text { le } \\ & \text { le } \\ & \text { ti } \\ & \end{array}$

\section{$\begin{array}{lll}(\mathrm{SMBG}) \quad \text { ter- } & (\mathrm{RTG} ; \mathrm{n}=43) \text { dan } \text { st } \\ \text { struktur "3 point } 7 & \text { group }(\mathrm{STG} ; \mathrm{n}=43)\end{array}$} tional Diabetes Federation (IDF) menyediakan beberapa contoh rejimen SMBG terfokus, salah satunya pelaksanaan SMBG "3 point 7 days" yaitu pengukuran SMBG pada waktu (sebelum dan 2 jam setelah makan, dan sebelum tidur) selama tujuh hari berturut-turut. Studi terkait " 3 point 7 days" secara signifikan dapat mengurangi hemoglobin terglikasi (HbA1c) pada pasien dengan pengobatan noninsulin. Namun, belum ada penelitian terkait "3 point 7 days" SMBG pada pasien diabetes dengan pengobatan insulin.

\section{Desain: RCT}

osive samping berjumlah 86 orang yaitu routine testing group (RTG; $\mathrm{n}=43$ ) dan structured testing

days" pada pasic diabetes dengan pengobatan insulin

$\underline{\text { Kriteria inklusi : }}$

Pasien DM tipe 1 atau DM tipe 2 berusia $\geq 20$ tahun dan $<90$ tahun; melakukan SMBG selama $\geq 3$ bulan; mampu menjawab kuesioner; menggunakan insulin dan / atau agonis reseptor peptida-1 seperti glukagon.

Kriteria eksklusi : Pasien DM dengan demensia dan atau gangguan psikologis/kejiwaan, dan hemoglobin terglikasi yang lebih tinggi dibandingkan dengan pasien yang tidak melaporkan 'rasa sakit,' sedangkan jumlah tes SMGD harian mereka sebanding. Pasien yang melaporkan 'rasa sakit' juga melaporkan bahwa penggunaan SMBG secara signifikan kurang penting.

Tidak ada perbedaan HbA1c yang signifikan antara RTG dan STG pada follow up 3 bulan.

Namun, STG telah memperbaiki HbA1c secara signifikan pada follow-up 6 bulan dibandingkan dengan RTG $(P=0,002)$. Nilai HbA1c pada kelompok STG menurun $0,5 \%$ dari 7,9 (SD 0,5) menjadi $7,4 \quad(0,7) \%$, sedangkan nilai HbA1c di kelompok RTG hanya menurun sebesar $0,1 \%$ dari $7,9(0,5)$ menjadi $7,8(0,7 \%)$.

55\% pasien pada kelompok STG bersedia untuk melanjutkan MBG terstruktur hingga mencapai taget penurunan $\mathrm{HbA} 1 \mathrm{c}$ sebesar $0,7 \%$.

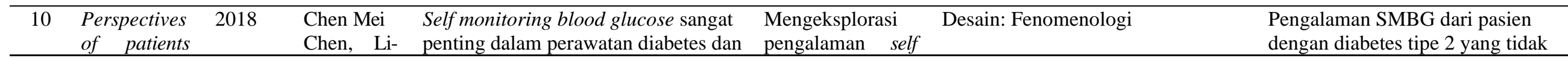




$\begin{array}{llll}\text { with non-in- } & \text { Chen } & \text { kontrol glikemik. Namun, pandangan monitoring blood } \\ \text { sulin treated } & \text { Hung, } & \text { pasien mengenai self monitoring glucose pada } \\ \text { type 2 diabe- } & \text { Yang Lin- } & \text { blood glucose jarang dibahas didalam pasien diabetes } \\ \text { tes } \text { on self- } & \text { Chen, Mei } & \text { literatur. Selain itu, keterlibatan tipe 2 yang tidak } \\ \text { monitoring } & \text { Chang Yeh } & \text { pasien dalam melakukan selfmonitor- diobati dengan in- } \\ \text { of blood glu- } & & \text { ing blood glucose secara konsisten sulin. } \\ \text { cose } & & \text { masih tergolong rendah. }\end{array}$

Purposive samping berjumlah 16 orang

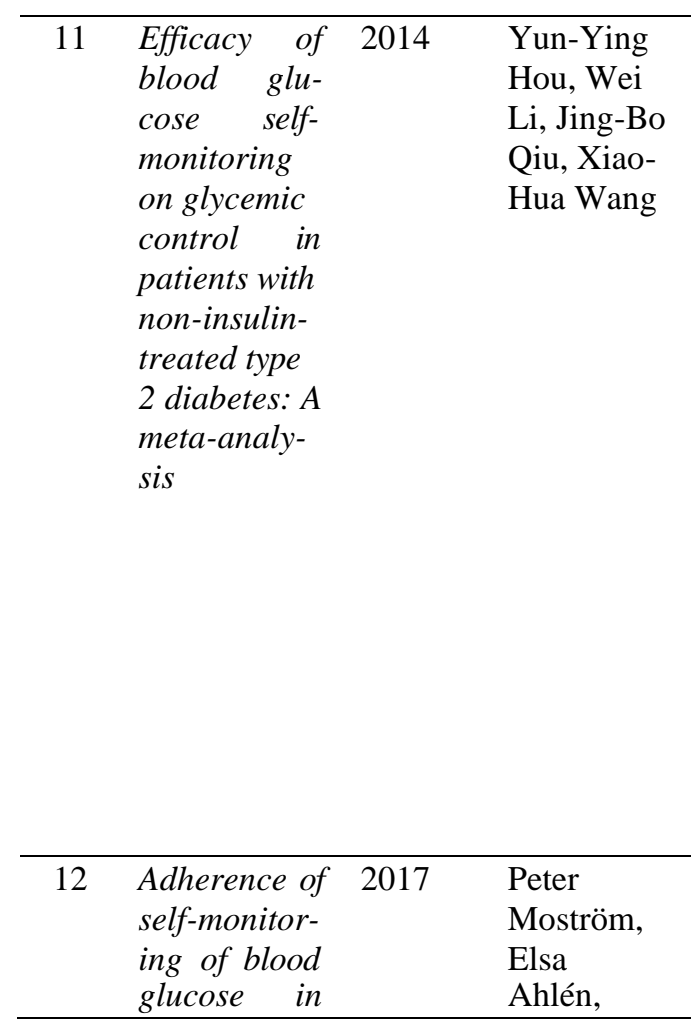

HbA1c merupakan metode emas un- Mengevaluasi ketuk mengevaluasi kontrol glikemik dimana nilai $\mathrm{HbA} 1 \mathrm{c}<7 \%$ mampu mengurangi risiko komplikasi diabetes dan meningkatkan prognosis. Namun, untuk mencapai tujuan tersebut, pasien diabetes diharuskan mengubah gaya hidup dan mengikuti rejimen pengobatan khusus yang secara efektif mengontrol kadar glukosa darah puasa dan glukosa post-prandial. Self monitoring blood glucose (SMBG) dapat membantu pasien diabetes yang diobati dengan insulin untuk mengetahui kadar glukosa darah dan meningkatkan kontrol glikemik meskipun hasi (RCT) menunjukkan bahwa keefektifan SMBG terhadap kontrol glikemik pada pasien diabetes tipe 2 yang dengan pengobatan non insulin masih kontroversial.

The American Diabetes Association

telah menganjurkan sejumlah pengukuran self monitoring blood glucose per hari pada pasien diabetes dengan

monitoring blood

glucose terhadap

kontrol glikemik

pada pasien diabe-

tes tipe 2 yang

tidak diobati

dengan insulin.
Mengevaluasi ke- Desain: Meta analisis. Penelusuran

$\begin{array}{ll}\text { Mengevaluasi } & \text { Desain: Cross sectional } \\ \text { tingkat kepatuhan } & \\ \text { pasien diabetes } & \begin{array}{l}\text { Purposive samping berjumlah } 600 \\ \text { tipe } 1 \text { dalam }\end{array} \\ \end{array}$

Kriteria inklusi: Memiliki diagnosis diabetes tipe 2 ; tidak mendapatkan pengobatan insulin; terlibat dalam self monitoring blood glucose setidaknya sekali dalam 6 bulan terakhir; berusia minimal 20 tahun; tidak memiliki gangguan mental atau kognitif manjuran self literatur dengan desain (RCT)

eratur dengan desain (RCT)

Jurnal dikumpulkan dari PubMed,

EMBASE, Cochrane Library,

CNKI, dan database VIP.

\author{
Library,
}

Analisis subkelompok menunjuk-

kan bahwa penerapan rejimen manajemen diabetes berdasarkan pada hasil self monitoring blood glucose secara efektif mengurangi tingkat HbA1c sebesar 0,42\%. Di sisi lain, tidak ada peningkatan yang signifikan dalam kontrol tingkat HbA1c yang diamati dengan penerapan self monitoring blood glucose saja.

Didapatkan tujuah artikel RCT. bahwa self monitoring blood glucose secara signifikan mengurangi kadar hemoglobin terglikasi HbA1c) sebesar 0,41\%.
Hasil didapatkan total 138 dari 314 peserta penelitian $43,9 \%$ (95\% CI $38,5 \%$ hingga $49,4 \%$ ) melakukan $\mathrm{SMBG} \geq 4$ kali per hari. tas frekuensi SMBG, refleksi gaya dan adaptasi terhadap pertuasi glukosa darah, dan faktor kelanjutan SMBG.

Accepted: 03/06/20 Published:30/06/20 
persons with type 1 diabetes in Sweden
Henrik Im- pengobatan insulin. Rekomendasi melakukan SMBG

berg, Per- yang dianjurkan setidaknya 4 kali per

Olof Hans- hari, atau 6-10 kali per hari untuk

son, Mar- mencapai kontrol metabolik yang

cus Lind

baik. Oleh karena itu, perlu diketahui

intensitas kepatuhan pasien terhadap pedoman self monitoring blood glu-

cose di Swedia yang sebelumnya belum pernah dilakukan. an menyelidiki Kriteria inklusi: Pasien diabetes tipe

prediktor kepatu- 1 dan $\geq 18$ tahun

han SMBG:

ketid-

alasan ketid-

akpatuhan, hub-

ungan antara frek-

uensi self monitor

ing blood glucose dengan $\mathrm{HbA1c}$.
Tiga alasan utama ketidakpatuhan yang dilaporkan terkait self monitoring blood glucose meliputi

keterbatasan waktu, lupa, dan kurangnya kesadaran diri.

Frekuensi self monitoring blood glucose signifikan terhadap nilai HbA1c (p <0,0001). 


\section{Pembahasan}

\section{Self monitoring blood glucose sebagai salah satu manajemen diri pasien DM terhadap kontrol glikemik dan persepsi HRQoL}

Sejak ditetapkannya diagnosis diabetes kepada pasien, maka manajemen diabetes berupa modifikasi kegiatan dalam kehidupan sehari-hari menjadi rutinitas yang harus dilakukan secara rutin oleh pasien. Namun, adanya kewajiban melakukan manajemen diri sekaligus ketakutan akan komplikasi diabetes baik akut maupun kronis memungkinkan adanya perubahan ke arah perburukan HRQoL pada diri pasien secara signifikan. Salah satu bagian dari manajemen diri diabetes yang diakui signifikan adalah self monitoring blood glucose (SMBG).

Self Monitoring Blood Glucose (SMBG) adalah pemeriksaan glukosa darah yang dilakukan secara mandiri oleh pasien di rumah. Pemeriksaan ini dianggap penting sebab fluktuasi kadar glukosa darah akan berubah setiap waktu sehingga adanya frekuensi pemantauan glukosa darah yang lebih banyak akan membawa manfaat bagi pasien. Hasil penelitian yang bertujuan menyelidiki parameter kontrol glikemik mana yang dikaitkan dengan persepsi yang lebih buruk dari HRQoL didapatkan Mean Glucose Levels (MGL) memiliki korelasi paling signifikan dengan persepsi HRQoL, yang diartikan bahwa self monitoring blood glucose (SMBG) memiliki manfaat untuk meningkatkan kualitas hidup dan kontrol glikemik. ${ }^{11}$

Dampak self monitoring blood glucose (SMBG) begitu penting sehingga direkomendasikan secara luas sebagai komponen manajemen diabetes. Oleh karena itu, pelaksanaan SMBG harus dilaksanakan dengan pendekatan yang lebih terstruktur dan terstandarisasi. The American Diabetes Association telah menganjurkan sejumlah pengukuran self monitoring blood glucose per hari pada pasien diabetes dengan pengobatan insulin. Rekomendasi yang dianjurkan setidaknya 4 kali per hari, atau 6-10 kali per hari untuk men- capai kontrol metabolik yang baik. ${ }^{12}$. International Diabetes Federation (IDF) menambahkan rejimen pelaksanaan SMBG yang mampu menurunkan nilai HbA1c dapat menggunakan skema "3 point 7 days" yaitu pengukuran SMBG pada waktu (sebelum dan 2 jam setelah makan, dan sebelum tidur) selama tujuh hari berturut-turut. ${ }^{13}$

\section{Kendala pelaksanaan SMBG}

Komplikasi diabetes yang terjadi erat dikaitkan dengan kegagalan melaksanakan manajemen diri. Dalam hal ini kendala dalam manajemen diri-self monitoring blood glucose- secara umum dapat dibagi ke dalam dua kategori. Kategori pertama berasal dari interinsik (dalam diri pasien) dan ekterinsik (luar diri pasien).

Kendala interinsik pertama yaitu adanya ketidakpatuhan pasien dalam melakukan SMBG secara rutin. Tiga alasan utama ketidakpatuhan yang dilaporkan terkait self monitoring blood glucose meliputi keterbatasan waktu, lupa, dan kurangnya kesadaran diri. ${ }^{12} \mathrm{Hal}$ ini didukung oleh sebuah penelitian dimana keterlibatan pasien dalam melakukan self monitoring blood glucose secara konsisten masih tergolong rendah. ${ }^{14}$ Kendala interinsik berikutnya yaitu kurang mengetahui pentingnya perawatan diri dan cara melakukan perawatan diri yg benar dimana sebagian besar pasien umumnya lebih patuh terhadap pengobatan namun tidak pada patuh pada bagian aktivitas fisik dan pemantauan glukosa darah mandiri. ${ }^{15}$

Berikutnya mengenai kendala ekterinsik, didapatkan bahwa adakalanya pasien telah melakukan self monitoring blood glucose dengan baik dan rutin, namun tetap terjadi kesalahan pelaporan nilai glukosa darah. Beberapa penyebab dari kesalahan pada pelaporan meliputi tidak ditemukannya dokumentasi tertulis terkait hasil SMBG, adanya pemalsuan verbal, dan upaya memanipulasi keakuratan glikometer. Faktor eksterinsik berikutnya yang juga kerap dialami oleh pasien yang menjalankan program self monitoring blood glucose yaitu adanya 
nyeri pada saat penusukan jarum. Nyeri tusukan jari merupakan salah satu beban mental penggunaan SMBG yang paling jelas. Meskipun telah ada perangkat glikometer yang dapat mengurangi rasa sakit saat tertusuk, namun hal tersebut menjadi beban utama manajemen diabetes secara keseluruhan.

\section{Peran perawat dalam pelaksanaan SMBG}

Penentuan tingkat hemoglobin terglikasi (HbA1c) adalah metode emas untuk mengevaluasi kontrol glikemik pada pasien diabetes. Oleh karena itu, mempertahankan tingkat $\mathrm{HbA} 1 \mathrm{c}$ pada $<7 \%$ dapat secara signifikan mengurangi risiko komplikasi diabetes dan meningkatkan prognosis. Namun, untuk mencapai tujuan tersebut, pasien diabetes diharuskan mengubah gaya hidup dan mengikuti manajemen diri yang secara efektif mengontrol kadar glukosa darah puasa dan glukosa post-prandial, melalui self monitoring blood glucose. ${ }^{16}$

Namun tidak dapat dipungkiri, adanya kendala dalam pelaksanaan self monitoring blood glucose mengakibatkan kegiatan ini tidak mampu berjalan lancar. Perawat merupakan profesi kesehatan yang posisinya mampu menginspirasi perubahan positif dan mengubah pemberian layanan kesehatan dengan berfungsi sebagai jembatan antara teori dan praktik. Dalam edukasi manajemen diri diabetes, praktik perawat diposisikan secara ideal untuk memberikan pemantauan, umpan balik yang disesuaikan, dan pendidikan tentang aspek-aspek kunci dari manajemen diri. ${ }^{17}$

Beberapa penelitian menunjukkan bahwa penggunaan SMBG terstruktur kombinasi dengan pendidikan dan dukungan tenaga kesehatan mampu mendorong perubahan perilaku yang diinginkan, meningkatkan motivasi dan pemberdayaan pasien, meningkatkan pemahaman pasien tentang rejimen pengobatan dan memfasilitasi intensifikasi terapi, yang mengarah pada peningkatan hasil klinis dan kualitas hidup. ${ }^{18}$ Hasil penelitian menjelaskan bahwa pasien diabetes yang mengikuti program pendidikan pasien komprehensif mengalami peningkatan dalam melakukan praktik perawatan diri. ${ }^{15}$ Hasil penelitian lainnya mengenai edukasi pada kelompok intervensi menunjukkan peningkatan $\mathrm{HbA1c}$, tekanan darah, BB, harapan, efikasi diri, dan perilaku manajemen diabetes yang semakin baik. ${ }^{7}$

\section{Kesimpulan}

Self monitoring blood glucose merupakan bagian dari manajemen diabetes yang potensial dan signifikan. Adapun manfaat dari pelaksanaan SMBG tidak hanya untuk mencegah komplikasi diabetes melalui kontrol glikemik (HbA1c), tetapi juga dapat meningkatkan HRQoL pasien. Namun, pada saat pelaksanaannya masih terdapat kendala. Oleh karena itu, keberadaan perawat sebagai sosok yang terdekat dengan pasien ketika merawat pasien dengan diabetes harus memberikan edukasi dan motivasi terkait pelaksanaan SMBG.

\section{Daftar Pustaka}

1. World Health Organization. Global Report On Diabetes. 2016;

2. International Diabetes Federation. Annual Report On Diabetes. 2016;

3. Kementerian Kesehatan RI. Undang-undang Republik Indonesia Nomor 38 Tahun 2014 tentang Keperawatan Kementerian Kesehatan RI. (2014). Undang-undang Republik Indonesia Nomor 38 Tahun 2014 tentang Keperawatan, Kemenkes RI. Retrieved from https://www.kemenkopmk.go.id/sites/defaul t/file. 2014;Kemenkes RI. Available from: https://www.kemenkopmk.go.id/sites/defaul t/files/produkhukum/UU Nomor 38 Tahun 2014.pdf.

4. Jones A, Olsen MZ, Perrild HJD, Willaing I. The psychological impact of living with diabetes: Descriptive findings from the DAWN2 study in Denmark. Prim Care Diabetes [Internet]. 2016;10(1):83-6. Available from: http://dx.doi.org/10.1016/j.pcd.2015.03.008

5. Aguiar CCT, Fernandes Vieira APG, Carvalho AF, Montenegro RM. Instrumentos de avaliação de qualidade de vida relacionada 
à saúde no diabetes melito. Arq Bras Endocrinol Metabol. 2008;52(6):931-9.

6. Hermanns N, Kulzer B, Kohlmann T, Jacob S, Landgraf W, Theobald K, et al. Treatment satisfaction and quality-of-life between type 2 diabetes patients initiating long- vs. intermediate-acting basal insulin therapy in combination with oral hypoglycemic agents a randomized, prospective, crossover, open clinical trial. Health Qual Life Outcomes [Internet]. 2015;13(1):1-13. Available from: http://dx.doi.org/10.1186/s12955-015-02794

7. Braga de Souza ACC, Felício JS, Koury CC, Neto JFA, Miléo KB, Santos FM, et al. Health-related quality of life in people with type 1 Diabetes Mellitus: Data from the Brazilian Type 1 Diabetes Study Group. Health Qual Life Outcomes [Internet]. 2015;13(1):0-9. Available from: http://dx.doi.org/10.1186/s12955-015-03960

8. Schunk M, Reitmeir P, Schipf S, Völzke H, Meisinger C, Ladwig KH, et al. Healthrelated quality of life in women and men with type 2 diabetes: A comparison across treatment groups. J Diabetes Complications [Internet]. 2015;29(2):203-11. Available from:

http://dx.doi.org/10.1016/j.jdiacomp.2014.1 1.010

9. Kuznetsov L, Griffin SJ, Davies MJ, Lauritzen T, Khunti K, Rutten GEHM, et al. Diabetes-specific quality of life but not health status is independently associated with glycaemic control among patients with type 2 diabetes: A cross-sectional analysis of the ADDITION-Europe trial cohort. Diabetes Res Clin Pract [Internet]. 2014;104(2):281-7. Available from: http://dx.doi.org/10.1016/j.diabres.2013.12.0 29

10. Alcubierre N, Rubinat E, Traveset A, Martinez-Alonso M, Hernandez M, Jurjo C, et al. A prospective cross-sectional study on quality of life and treatment satisfaction in type 2 diabetic patients with retinopathy without other major late diabetic complications. Health Qual Life Outcomes. 2014;12(1):1-12.

11. Paula JS, Braga LD, Moreira RO, Kupfer R. Correlation between parameters of selfmonitoring of blood glucose and the perception of health-related quality of life in patients with type 1 diabetes mellitus. Arch Endocrinol Metab. 2017;61(4):343-7.

12. Moström P, Ahlén E, Imberg H, Hansson PO, Lind M. Adherence of self-monitoring of blood glucose in persons with type 1 diabetes in Sweden. BMJ Open Diabetes Res Care. 2017;5(1).

13. Kato N, Cui J, Kato M. Structured selfmonitoring of blood glucose reduces glycated hemoglobin in insulin-treated diabetes. J Diabetes Investig. 2013;4(5):450-3.

14. Chen CM, Hung LC, Chen YL, Yeh MC. Perspectives of patients with non-insulintreated type 2 diabetes on self-monitoring of blood glucose: A qualitative study. J Clin Nurs. 2018;27(7-8):1673-83.

15. Tewahido D, Berhane Y. Self-care practices among diabetes patients in Addis Ababa: A qualitative study. PLoS One. 2017;12(1):110.

16. Hou Y, Li W, Qiu J, Wang X. Efficacy of blood glucose self-monitoring on glycemic control in patients with non-insulin-treated type 2 diabetes: A. Int J Nurs Sci [Internet]. 2014;1(2):191-5. Available from: http://dx.doi.org/10.1016/j.ijnss.2014.05.003

17. Azami G, Soh KL, Sazlina SG, Salmiah MS, Aazami S, Mozafari M, et al. Effect of a Nurse-Led Diabetes Self-Management Education Program on Glycosylated Hemoglobin among Adults with Type 2 Diabetes. J Diabetes Res. 2018;2018.

18. Lalić NM, Lalić K, Jotić A, Stanojević D, Živojinović D, Janićijević A, et al. The Impact of Structured Self-Monitoring of Blood Glucose Combined with Intensive Education on HbA1c Levels, Hospitalizations, and Quality-of-Life Parameters in Insulin-Treated Patients with Diabetes at Primary Care in Serbia: The Multicenter SPA-EDU Stud. J Diabetes Sci Technol. 2017;11(4):746-52.

19. Astuti, Astuti, and Agus Purnama. "Pengaruh Membaca Al-Quran terhadap Kadar Glukosa Darah pada Pasien Diabetes Melitus di RSUD Cengkareng Tahun 2018." Jurnal Ilmiah Ilmu Keperawatan Indonesia 9.02 (2019): 577-584. 